\title{
Dating Behavior and Age at First Time having Premarital Sexual Intercourse on Young Men in Indonesia
}

\author{
Uswatun Hasanah Purnama Sari ${ }^{1}$, Apik Indarty Moedjiono ${ }^{1 *}$, M. Nadjib Bustan ${ }^{2}$ \\ ${ }^{1}$ Department of Reproduction Health, Faculty of Public Health, Hasanuddin University, Makassar, Indonesia; ${ }^{2}$ Department of \\ Statistics, Faculty of Mathematics and Natural Sciences, Makassar, Indonesia
}

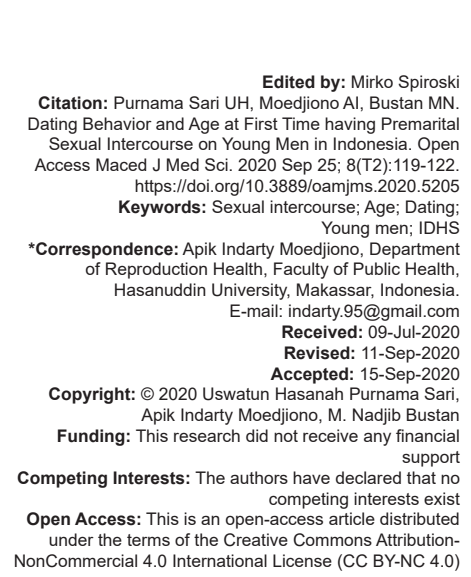

\section{Introduction}

Adolescence is a period of growth and development that occurs dynamically and rapidly both physically, psychologically, intellectually, socially, and sexual behavior that is associated with the onset of puberty. The UN mentions young people (youth) for ages 15-24 years. This is then incorporated into the terminology of young people (young people) which covers the ages of 10-24 years. Health problems in adolescence are one of the important problems in the lifecycle. One of the health problems of adolescents today is risky sexual behavior [1].

Based on the WHO data, in some developing countries show about $40 \%$ of adolescents aged 18 years have had sex even without marriage. As a result of sexual intercourse, around $12 \%$ have been positively affected by sexually transmitted infectious disease; around $27 \%$ are HIV positive [2]. Data Center for Disease Control in a study conducted on several high school students in the US in 2011 , about $47.4 \%$ of students had sexual intercourse (sexual intercourse). Around $33.7 \%$ had sexual intercourse in the past 3 months, and $15.3 \%$ had sexual relations with four or more people during their lives [3].
Research in sub-Saharan Africa, reports that up to $25 \%$ of children aged $15-19$ have had sexual relations before the age of 15 years. In most countries, $\geq 5 \%$ of women are reported to be married before the age of 15 , and $>20 \%$ have given birth. First time having sex and giving birth is more common in women who live in rural areas that are less educated. Having sex with changing partners is more common in men than women, but decreases with time [4]. The results of the 2012 Adolescent Reproductive Health Survey showed that adolescent knowledge about reproductive health was inadequate, where only $35.3 \%$ of adolescent girls and $31.2 \%$ of adolescent boys aged 15 years knew that women could get pregnant with one times of sexual intercourse, and only $9.9 \%$ of teenage girls and $10.6 \%$ of teenage boys have comprehensive knowledge about HIVIAIDS [5].

The National Family Planning Coordinating Board (BKKBN) examined 8084 adolescents aged 15-24 years in 20 districts in West Java, Central Java, East Java, and Lampung. Sexual behavior in adolescents aged 15-24 years continues to increase every year, due to dating behavior that is often excessive [6].

Changes in views on sexuality are thought to have caused a major shift in sexual habits and lifestyles 
especially young people [7]. Research by Ninik at 2010 in Deran shows that there is a significant relationship between unsafe sexual behavior and reproductive health knowledge with a $p=0.000$ with alpha 0.05 [8].

Teenage boys have the opportunity to engage in risky sexual behavior in dating 6.8 times greater than teenage girls. This is related to the hormone testosterone which causes a man to be more sensitive to stimulation which causes sexual sensations. Testosterone levels in the blood will also make the brain activate the mind, so adolescent boys are more prone to erections compared to adolescent girls if stimulated or sexually stimulated, both from vision, hearing, and also touch [9].

This evidence reflects that the lack of understanding of adolescents about healthy life skills and the risk of sexual relations. Findings from various studies indicate that increased sexual activity among adolescents, not accompanied by increased knowledge about sexual and reproductive health [10]. Knowledge lower 1.5 times more likely to perform premarital sexual behavior at risk than adolescents who have high knowledge. This low knowledge can be caused by a lack of proper and correct understanding of the risks and impacts of the actions taken [11]. On the description of these problems, researchers are interested in conducting research on the characteristics of adolescents at first sexual intercourse.

\section{Materials and Methods}

The 2017 Indonesian Demographic and Health Survey (SDKI) was conducted by the Central Statistics Agency (BPS) and in collaboration with the National Population and Family Planning Agency (BKKBN) and the Ministry of Health. Survey funding was provided by the Government of Indonesia. In implementation, Indonesia got help from Inner City Fund International through project Demographic and Health Surveys (DHS) program, a program of United States Agency for International Development (USAID) provided funding and technical assistance in the implementation of population survey and health in many countries.

Data collection took place in 34 provinces, 47,963 households in Indonesia. This type of research is quantitative with a cross-sectional method based on the 2017 IDHS data design. The population is all unmarried men aged 15-24 years who were successfully interviewed as many as 13,079 people. The research sample is as many as 12,523 people after Mel Alui process of cleaning based on the variables examined and the answers of respondents who missed (the symbol 9 on the data IDHS 2017) as well as the answers do not know (symbol 8 on the data IDHS 2017) respondent on the dependent variables.
In this study, the data collection method used is to use secondary data from the 2017 IDHS data on the Adolescent Reproductive Health sub-survey. This data were obtained from the National Population and Family Planning Agency (BKKBN) of Indonesia. Before data collection, researchers observed the 2017 IDHS questionnaire to find out any questions relating to sexual behavior and factors related to premarital sexual behavior of young men.

Data analysis uses univariate analysis which aims to explain the characteristics of male teenage respondents. Univariate analysis functions to explain or describe the characteristics of the research variables processed by looking at the percentage.

\section{Results}

The results of the study in Table 1 show that the distribution of young men with the highest number was at the age of 15 years, namely, as many as 1686 people $(13.5 \%)$ while the respondents with the smallest number were at the age of 24 years as many as 743

Table 1: Distribution of young men by age in Indonesia in 2017

\begin{tabular}{lll}
\hline Age & Frequency $(\mathrm{n})$ & Percentage \\
\hline 15 years & 1686 & 13.5 \\
16 years & 1652 & 13.2 \\
17 years & 1777 & 14.2 \\
18 years & 1339 & 10.7 \\
19 years & 1263 & 10.1 \\
20 years & 1163 & 9.3 \\
21 years & 1003 & 8.0 \\
22 years & 1022 & 8.2 \\
23 years & 875 & 7.0 \\
24 years & 743 & 5.9 \\
\hline
\end{tabular}

Table 2: Distribution of respondents by age for first time conducting sexual relations in young men in Indonesia in 2017

\begin{tabular}{lll}
\hline First time for sexual intercourse & Frequency $(\mathrm{n})$ & Percentage \\
\hline 11 years & 2 & 0.2 \\
12 years & 10 & 0.8 \\
13 years & 19 & 1.5 \\
14 years & 45 & 3,6 \\
15 years & 134 & 10.7 \\
16 years & 194 & 15.4 \\
17 years & 254 & 20.2 \\
18 years & 216 & 17.2 \\
19 years & 141 & 11.2 \\
20 years & 144 & 11.4 \\
21 years & 54 & 4,3 \\
22 years & 29 & 2,3 \\
23 years & 5 & 0.4 \\
98 (do not know) & 11 & 0.9 \\
\hline
\end{tabular}

people $(5.9 \%)$. Table 2 illustrates the distribution of young men by the age of first doing sexual intercourse on adolescent the largest man was at age 17 years that as many as 254 people (20.2\%), while the smallest percentage in 11 years is that as many as $2(0.2 \%)$.

Table 3 illustrates the distribution of male adolescents based on the highest level of education, the highest being at the level of high school/vocational/ MA/equivalent level as many as 7370 people (59.2\%). While the smallest level of tertiary education is found at the Academy/DI/DII/DIII level which is 266 people 
Table 3: Distribution of respondents based on youth education in Indonesia at 2017

\begin{tabular}{lll}
\hline Highest education & Frequency $(\mathrm{n})$ & Percentage \\
\hline Never/currently in school & 64 & 0.5 \\
SD/MI/Equal & 1142 & 9.1 \\
SMP/MTs/Equivalent & 2028 & 16.2 \\
SMA/SMK/MA/Equal & 7370 & 58.9 \\
ACADEMY/DI/DII/DIII & 266 & 2.1 \\
Diploma IV/University & 1652 & 13.2 \\
\hline
\end{tabular}

Table 4: Distribution of respondents who are dating on male young in Indonesia in 2017

\begin{tabular}{lcc}
\hline In a relationship & Frequency $(\mathrm{n})$ & Percentage \\
\hline In a relationship & 5476 & 43.7 \\
Not dating & 7047 & 56.3 \\
\hline
\end{tabular}

(2.1\%). Table 4 illustrates that the contribution of male adolescents who are not dating is as much as 7047 people $(56.3 \%)$ compared to those who are dating that is as many as 5476 people $(43.7 \%)$.

\section{Discussion}

This study shows that the characteristic description of adolescents is that most young men are 15 years old, the highest level of education is at the high school/vocational/MA/equivalent level, male adolescents who are not dating are higher than those who are not dating, and adolescents most men have the first sexual intercourse is at the age of 17 .

The distribution of male adolescents based on age for the first time having sexual intercourse with the biggest male adolescents is at the age of 17 years which is 254 people $(20.2 \%)$, while the smallest percentage is at the age of 11 years which is as much as two people $(0.2 \%)$.

This is consistent with research Rosdarni et al. [12] showed that the data IDHS 2007 in Kendari recorded $13.3 \%$ of adolescents aged 15-19 years were surveyed admitted to having sex Cuma time at the age of 15 years. Adolescence or adolescence comes from the Latin word adolescere (the word adolescentia which means adolescent) which means "to grow" or "grow into adulthood." The term adolescence as used today has a broader meaning, which includes mental, emotional, social, and physical maturity [13].

Indonesia has a population of \pm 233 million. Based on 2009 BKKBN data, the number of adolescents aged 10-24 years reached 64 million or $27.6 \%$ of the total population of Indonesia and in 2010, it increased to 657 million. In the perspective of population collected by the National Population and Family Planning Agency (BKKBN), the size of the population of this youth group will greatly influence population growth in the future. Teenagers need to get serious attention considering that they are still in school age and working age, they will enter the workforce and enter reproductive age [14]

The survey, which uses secondary data from the 2012 IDHS on adolescent reproductive health, was conducted on unmarried adolescent girls and men. The results are $8.3 \%$ of teenage boys and $1 \%$ of teenage girls have premarital sex. Most sexual intercourse was carried out in adolescents aged 20-24 years by $9.9 \%$ and $2.7 \%$ at the age of $15-19$ years. The same survey almost $80 \%$ of respondents had held hands, $48.2 \%$ of male teenagers, $29.4 \%$ of female teens had kissed, and $29.5 \%$ of male teenagers and $6.2 \%$ of female teenagers had stimulated each other of the total teenagers surveyed. The influence of the increase was through mass media, print media, TV and radio, online web, and other social networks. And the influence of peers who have had premarital sex [6]

Adolescents aged 20-24 years have 2.3 times the chance to have risky sexual behavior compared to adolescents aged 15-19 years. This is influenced by changes and developments that occur during adolescence. As adolescents get older, the reproductive organs that influence sexual drive develop so that a person begins to feel clearly the increase in sex drive that can arise in the form of attraction toward the opposite sex and desire to get sexual satisfaction [10]. In other words, adolescents aged 20-24 years will undergo a process of sexual maturity that is more advance than adolescents aged $15-19$ years old so late teens has sexual urges greater than the initial or middle teens. Similar research shows the same thing, there is a significant relationship between age and adolescent risk behavior, including premarital sexual behavior.

The results of the Indonesian Demographic and Health Survey 2012 in Wijayanti show that adolescents begin dating at the age of 15-17 years. Approximately $33 \%$ of female adolescents and $34.5 \%$ of male adolescents aged 15-19 years dating before the age of 15 years. Based on the results of the 2002 IDHS and 2007, premarital sexual relations were mostly carried out at the age of $20-24$ years, $9.9 \%$ and $15-19$ years of age $2.7 \%$ [15], [16], [17].

This is consistent with the results of research Rusmiati [10] that there is a significant relationship $(p=0.000 ; \mathrm{OR}=2.3 ; \mathrm{Cl}=2.1--2.6)$ between the ages of age (divided into ages 15-19 years and 20-24 years) with sexual behavior in dating.

\section{Conclusion}

It is expected that the role of parents, schools, health centers, and health offices in providing information related to comprehensive reproductive health education. 


\section{References}

1. Yanti NK, Jati $U$ Dewi S. Hubungan persepsi kesehatan reproduksi dengan perilaku seksual mahasiswi angkatan 2012 dan 2013 prodi D-III kebidanan di poltekkes kemenkes permata Indonesia. Health Care Med. 2018;3(3):22-8. https:// doi.org/10.35730/jk.v10i1.371

2. Mangando EN, Lampus BS, Siagian IE, Kandou GD, Pandelaki AJ, Kaunang WP. Hubungan antara pengetahuan dan sikap remaja dengan tindakan seks pranikah pada siswa kelas XI Di SMK Negeri 2 Manado. J Kedokt Komunitas Tropik. 2014;2(1):37-43. https://doi.org/10.31219/osf.io/6ayjn

3. Mahmudah M, Yaunin Y, Lestari Y. Faktor-faktor yang Berhubungan dengan perilaku seksual remaja di kota Padang. J Kesehat Andalas. 2016;5(2):448-55. https://doi.org/10.25077/ jka.v5i2.538

4. Doyle AM, Sue NM, Mary L. The sexual behaviour of adolescents in Sub-Saharan Africa: Patterns and trends from national surveys. Trop Med Int Health. 2012;17(7):796807. $\quad$ https://doi.org/10.1111/j.1365-3156.2012.03005.x PMid 22594660

5. Afrianti N, Mudatsir M, Teuku T. Analisis implementasi program pelayanan kesehatan peduli remaja (PKPR). IImu Keperawatan. 2017;5(2):15-25.

6. Fauziah AN, Siti M. Pengaruh umur dan tingkat pendidikan terhadap perilaku seks pranikah pada remaja Di RW 03 kalurahan Mojosongo Surakarta. Indones J Med Sci. 2017;4(2):202-7.

7. Nirmalasari NP, Adiguna S, Ni Made DP. Prevalensi Dan karakteristik infeksi menular seksual di klinik anggrek UPT Ubud II Pada Bulan Januari-Desember 2016. Med Udayana. 2018;7(4):169-75.

8. Deran HM. Tingkat Pengetahuan Kesehatan Reproduksi Remaja Yang Diberikan Oleh Konselor Sebaya Di SMAN 5 Bekasi (Skripsi). Depok: Universitas Indonesia; 2013. https:/l doi.org/10.24036/0201321878-0-00

9. Ningtyastuti YE, Suryani E. Pengaruh mengkonsumsi jambu biji merah terhadap peningkatan Kadar hemoglobin ibu hamil di kelurahan Bandung kecamatan Ngrampal kabupaten Sragen. J Indones Midwifery. 2018;6(2):61-8. https://doi.org/10.33023/ jikeb.v4i1.148

10. Rusmiati D, Sutanto PH. Sikap remaja terhadap keperawanan dan perilaku seksual dalam berpacaran. J Kesehat Masyarakat Nasional. 2015;10(1):29-36. https://doi.org/10.21109/kesmas. v10i1.815

11. Mariani NN, Dian FA. Faktor-faktor yang mempengaruhi perilaku seksual remaja di SMP Negeri 15 Kota Cirebon Tahun 2017. J Care. 2017;5(3):443-56. https://doi.org/10.33366/cr.v5i3.711

12. Rosdarni R, Djaswadi D, Sumarni DW. Pengaruh faktor personal terhadap perilaku seksual pranikah pada remaja. $J$ Kesehatan Masyarakat Nasional. 2015;9(3):214-21. https://doi. org/10.21109/kesmas.v9i3.567

13. Asmara DA. Faktor Yang Tidak Berhubungan Dengan Perilaku Seksual Pranikah Berisiko Kehamilan Tidak Diinginkan Pada Mahasiswa Yang Bertempat Tinggal Di Kos "Las Vegas" (Studi Kasus pada Universitas X di Kota Semarang) (Skripsi). Semarang: Universitas Negeri Semarang; 2016. https://doi. org/10.26714/jk.6.1.2017.28-34

14. Kahayani M, Dyah WS. Hubungan pengetahuan dengan kesiapan anak usia 10-12 tahun dalam mengahdapi perkembangan pubertas. Nurs News. 2018;3(1):501-12.

15. Muhith A, Winarti E, Perdana SS, Haryuni S, Rahayu KI, Mallongi A. Internal locus of control as a driving factor of early detaction behavior of servical cancer by inspection visual of acetic acid method. Open Access Maced J Med Sci. 2020;8(E):113-6. https://doi.org/10.3889/oamjms.2020.4341

16. Mallongi A, Birawida AB, Astuti RD, Saleh M. Effect of lead and cadmium to blood pressure on communities along coastal areas of Makassar, Indonesia. Enferm Clín. 2020;30(4):313-7. https:// doi.org/10.1016/j.enfcli.2020.03.001

17. Wijayanti $\mathrm{AC}$, Robi'i $\mathrm{PH}$. Hubungan antara sikap dan peran teman sebaya dengan perilaku pacaran remaja di kecamatan Kartasura Kabupaten Sukoharjo. J Kesehatan Masyarakat Khatulistiwa. 2017;4(3):206-11. https://doi.org/10.29406/jkmk. v4i3.851 